\title{
Pengaruh Strategi Pembelajaran dan Kemampuan Berpikir Kritis Terhadap Hasil Belajar Sejarah Siswa SMA Negeri 72 Jakarta
}

\author{
Oleh: Veronika Horohiung, Sarkadi, Murni Winarsih \\ Pendidikan Sejarah Pascasarjana Universitas Negeri Jakarta \\ veronikahorohiung@gmail.com
}

\begin{abstract}
The aim of this research is to find The influence of Instructional Strategy and Critical Thinking to History Learning Outcomes in SMA Negeri 72 Jakarta. The type of this research is used experiment design treatment method. The Instrument that used to know the learning outcomes is Multiple Choice, and the instrument that used to know the result of Critical Thinking is Quisioner. The result of this research refer to: (1) to history learning outcomes that was giving PBL Instructional Strategy is higher than students who was giving Direct Instructional. (2) there is influenace interaction between Instructional Strategy and Critical thinking. (3) history learning outcomes that was giving PBL Instructional Strategy and has Critical Thinking is higher than student who was giving Direct Instructional Strategy and has high Critical Thinking. (4) history learning outcomes that was giving PBL Instructional Strategy and the Critical Thinking is lower than student who was giving Direct Instructional Strategy and has low Critical Thinking.

Keywords: History Learning Outcomes, Instructional Strategy, Critical Thinking
\end{abstract}

\begin{abstract}
Abstrak: Penelitian ini bertujuan untuk mengetahui pengaruh strategi pembelajaran dan kemampuan berpikir kritis terhadap hasil belajar sejarah siswa di SMA Negeri 72 Jakarta. Jenis penelitian yang digunakan adalah penelitian kuantitatif dengan menggunakan metode eksperimen desain treatmen by level $2 \times 2$. Populasi terdiri dari seluruh siswa kelas XI IIS. Sampel terdiri dari dua kelas yaitu kelas XI IIS 2 dan XI IIS 3 dengan jumlah 60 orang. Instrumen yang digunakan untuk hasil belajar adalah tes pilihan ganda dan yang digunakan untuk kemampuan berpikir kritis adalah kuesioner. Hasil penelitian ini menunjukkan bahwa: (1) hasil belajar siswa yang diberikan strategi pembelajaran PBL lebih tinggi dari siswa yang diberikan strategi pembelajaran langsung (2) terdapat pengaruh interaksi antara strategi pembelajaran dan kemampuan berpikir kritis (3) hasil belajar sejarah siswa yang diberikan strategi pembelajaran PBL dan memiliki kemampuan berpikir kritis tinggi lebih tinggi dari siswa yang diberikan strategi pembelajaran langsung dan memiliki kemampuan berpikir kritis tinggi (4) hasil belajar sejarah siswa yang diberikan strategi pembelajaran PBL dan memiliki kemampuan berpikir kritis rendah lebih rendah dari siswa yang diberikan strategi pembelajaran langsung dan memiliki kemampuan berpikir kritis rendah.
\end{abstract}

Kata Kunci: hasil belajar sejarah, strategi pembelajaran, kemampuan berpikir kritis

\section{PENDAHULUAN}

Pembelajaran adalah proses interaksi antara siswa dan guru yang dilakukan pada suatu lingkungan belajar. Proses pembelajaran berlangsung sepanjang hayat dan terjadi di mana saja. Guru mempunyai peranan penting dalam menumbuhkan minat belajar siswa dan memotivasi siswa untuk 
berprestasi. Masalah pembelajaran terus berkembang mengikuti perkembangan zaman, inovasi-inovasi dalam kegiatan pembelajaran wajib dilakukan agar kegiatan pembelajaran semakin efektif.

Hasil observasi awal di SMA Negeri 72 Jakarta menunjukkan bahwa tidak banyak siswa yang tertarik pada pelajaran sejarah. Siswa memiliki pengetahuan dan pemahaman yang berbeda tentang materi pelajaran sejarah. Masalah yang dihadapi dalam proses pembelajaran sejarah adalah penggunaan strategi yang kurang tepat. Guru lebih sering menggunakan pembelajaran konvensional dimana siswa lebih diarahkan untuk mengolah informasi sejarah dengan cara menghafal dan menerima materi secara pasif. Pembelajaran di kelas dilaksanakan secara monoton dan kurang mengembangkan kemampuan berpikir kritis siswa.

Beberapa siswa belum belajar sampai pada tingkat pemahaman dalam konsep-konsep, fakta, teori pada materi pelajaran sejarah. Siswa berpandangan bahwa materi pembelajaran sejarah terlalu bersifat teoritis dan pelajaran sejarah dianggap hanya sekedar pelajaran pelengkap. Sebagian siswa mengerjakan tugas dan menjawab pertanyaan hanya berpatokan pada buku teks yang biasa dipakai di kelas tanpa mengolah proses berpikir dan bernalar dengan baik dan kreatif. Hal tersebut kemungkinan disebabkan oleh keterbatasan guru dalam mengakses informasi baru mengenai pendidikan sejarah.

Sebagai pengajar guru harus memiliki kemampuan mengajar yang baik dalam proses pembelajaran untuk mencapai kompetensi dasar. Pembelajaran bertujuan untuk membantu proses belajar siswa dan memberikan perubahan bagi siswa. Perubahan yang terjadi terlihat pada sikap, pengetahuan, keterampilan, motivasi, minat siswa dalam belajar dan meningkatnya hasil belajar.

Sebagai pendidik, guru dituntut untuk profesional dalam melaksanakan tugas tanggung jawabnya dalam suatu proses pembelajaran. Pembelajaran yang berkualitas dan bermakna tergantung pada guru mempersiapkan pembelajaran dan pengelolaan kelas. Guru harus menyusun perencanaan pembelajaran dengan menggunakan strategi pembelajaran yang tepat sesuai dengan tujuan, materi, kondisi kelas dan karakteristik siswa. Strategi pembelajaran adalah salah satu unsur yang penting dalam keberhasilan proses pembelajaran di kelas. Penerapan strategi pembelajaran sangat penting, terutama pada saat mengajar siswa yang berbeda dari segi kemampuan, pencapaian, kecenderungan, dan minat belajarnya (Basri 2015:24).

Terwujudnya kualitas pembelajaran merupakan tanggung jawab profesional guru yang dilaksanakan melalui pengalaman belajar yang bermakna dan fasilitas belajar yang diterima siswa. Seharusnya siswa diberi kesempatan untuk mengembangkan kemampuan berpikir kritis pada pelajaran sejarah untuk memecahkan masalah dan pembelajaran lebih efektif dan 
aplikatif dalam kehidupan sehari-hari. Kemampuan berpikir kritis pada pelajaran sejarah dianggap penting karena sejarah merupakan pelajaran yang menekankan pada peristiwa-peristiwa masa lampau dengan nilai-nilai yang terkandung di dalamnya. Pelajaran sejarah bukan sekedar pelajaran menghafal dan menerima informasi, melainkan menjadi alat bagi guru untuk membangkitkan semangat nasionalisme siswa dan kesadaran berbangsa yang bermartabat.

Pembelajaran sejarah berfungsi untuk menyadarkan siswa akan adanya proses perubahan dan perkembangan masyarakat dalam dimensi waktu dan untuk membangun perspektif serta kesadaran sejarah dalam menemukan, memahami, dan menjelaskan jati diri bangsa di masa lalu, masa kini, dan masa depan di tengah-tengah perubahan dunia (Leo Agung dan Wahyuni 2013:39). Pembelajaran sejarah harus dikemas dengan baik agar tujuan pembelajaran dapat dicapai dengan maksimal. Guru harus menyusun perencanaan pembelajaran dengan menggunakan strategi pembelajaran yang tepat sesuai dengan tujuan, materi, kondisi kelas dan karakteristik siswa. Pembelajaran juga harus difasilitasi dengan media, metode dan sumber belajar bagi peserta didik untuk mencapai target belajar.

Penelitian ini perlu dilakukan mengingat masih banyak guru yang belum menerapkan strategi pembelajaran yang tepat untuk meningkatkan hasil belajar siswa. Strategi pembelajaran Problem Based Learning (PBL) dirasa cukup tepat untuk digunakan agar siswa dapat mengembangkan kemampuan berpikir kritis dalam pelajaran sejarah. Melalui pembelajaran PBL siswa dapat manaruh minat yang tinggi terhadap pelajaran sejarah.

Gagne (2005:48-49) mengkategori- kan lima kemampuan dalam capaian hasil belajar yaitu keterampilan intelektual, strategi kognitif, sikap, informasi verbal, dan keterampilan motorik.

Richey (2011:136) mengemukakan bahwa "Problem Based Learning (PBL) is an instructional strategy used to prepare students to better problem solvers" artinya PBL adalah strategi yang digunakan untuk mempersiapkan siswa menjadi seorang yang dapat memecahkan masalah dengan baik. Spector (2013:299) menyatakan bahwa "direct instruction is learning that involves a teacher or tutor or instructional system in making decisions for learners, indicating which resources to use and what activities to pursue". Artinya pembelajaran langsung adalah pembelajaran yang melibatkan guru atau tutor atau sistem intruksional dalam membuat keputusan kepada siswa terhadap sumber belajar yang akan digunakan dan kegiatan yang mesti dilakukan dalam mengajar.

Brooke dan Parker (2012:24) mengemukakan bahwa berpikir kritis berbeda konteks dengan berpikir dengan baik, berpikir keras atau penyelesaian masalah. Berpikir kritis merupakan sisi lain dari kegiatan berpikir dan lebih 
menekankan pada bagaimana seseorang mengolah cara berpikir dalam upaya mengevaluasi dan pengambilan keputusan.

Penelitian yang relevan dengan penelitian ini adalah yang dilakukan oleh Satish Nargundkar dengan judul penelitian "A Guide Problem Based Learning (PBL) Approach: Impact on Critical Thinking". Hasil penelitiannya menunjukkan bahwa pendekatan PBL yang diuji di sini menjadi lebih efektif untuk sebuah kebutuhan kelas dari pada pembelajaran ceramah. Pembelajaran PBL secara keseluruhan berguna untuk meningkatkan pembelajaran maupun kemampuan berpikir kritis.

Penelitian ini bertujuan untuk mengetahui: (1) perbedaan hasil belajar sejarah antara siswa yang diberikan strategi pembelajaran PBL dengan siswa yang diberikan strategi pembelajaran langsung (2) pengaruh interaksi antara strategi pembelajaran dan kemampuan berpikir kritis terhadap hasil belajar sejarah siswa (3) perbedaan hasil belajar sejarah antara siswa yang memiliki kemampuan berpikir kritis tinggi dan diberikan strategi pembelajaran PBL dengan siswa yang diberikan strategi pembelajaran langsung (4) perbedaan hasil belajar sejarah antara siswa yang memiliki kemampuan berpikir kritis rendah dan diberikan strategi pembelajaran PBL dengan siswa yang diberikan strategi pembelajaran langsung.

\section{METODE}

Metode yang digunakan dalam penelitian ini adalah eksperimen dengan Desain Treatmen by level $2 \times 2$. Penelitian ini merupakan penelitian eksperimen menggunakan satu kelas kontrol dengan strategi pembelajaran langsung dan satu kelas eksperimen dengan strategi pembelajaran PBL. Populasi target dalam penelitian ini adalah seluruh siswa SMA Negeri 72 Jakarta. Populasi terjangkau adalah seluruh siswa kelas XI IIS. Sampel dalam penelitian ini dilakukan dengan teknik random sampling yang nantinya akan diperoleh satu kelas kontrol dan satu kelas sebagai kelas eksperimen. Jumlah siswa yang menjadi subjek penelitian adalah 60 siswa dibagi menjadi dua kelompok masing-masing terdiri dari 30 siswa.

Sebelum diberikan perlakuan, dilakukan pembagian kuesioner untuk mengetahui kemampuan berpikir kritis siswa. Skor pengisian kuesioner tersebut disusun berdasarkan skor tertinggi ke skor yang terendah. Setiap kelas ditetapkan 27\% dari ranking teratas digolongkan sebagai kelompok siswa yang memiliki kemampuan berpikir kritis tinggi dan 27\% dari ranking terbawah digolongkan sebagai kelompok siswa yang memiliki kemampuan berpikir kritis rendah (Sugiyono 2015:353).

Data yang dikumpulkan dalam penelitian ini meliputi data hasil belajar dan kemampuan berpikir kritis siswa pada mata pelajaran sejarah. Jenis instrumen yang digunakan adalah tes hasil belajar sejarah berupa tes piihan 
ganda dengan uji validitas menggunakan rumus Point Biserial Corelation dan uji reliabilitas menggunakan rumus KR20. Jenis instrument kemampuan berpikir kritis berupa kuesioner dengan uji validitas menggunakan koreasi Product Moment dan reliabilitas menggunakan Alpha Cronbach.

Data yang diperoleh melalui instrumen penelitian dianalisis menggunakan analisis deskriptif dan inferensial. Analisis deskriptif dilakukan dengan penyajian tabel distribusi, histogram, rata-rata dan simpangan baku. Uji normalitas dalam penelitian ini menggunakan Uji Liliefors. Sedangkan uji homogenitas menggunakan Uji Bartlett pada taraf $\alpha=0.05$. Uji hipotesis dalam penelitian ini menggunakan uji analisis variansi (ANAVA) untuk menguji efek utama dan pengaruh interaksi antar A dan B. Pengujian dilanjutkan dengan menggunakan Uji Tuckey untuk melihat hasil perbandingan di antara kelompok perlakuan penelitian.

\section{HASIL}

Pengujian hipotesis dilakukan untuk menguji semua efek utama dan efek interaksi terhadap hasil belajar dengan menggunakan analisis varians dua jalur (ANAVA) desain treatmen by level $2 \times 2$. Efek utama data peneitian ini adalah pengaruh penggunaan strategi pembelajaran (PBL dan Langsung) terhadap hasil belajar sejarah siswa SMA Negeri 72 Jakarta. Efek interaksi yaitu pengaruh interaksi antara siswa yang diberikan strategi pembelajaran dengan kemampuan berpikir kritis tinggi dan rendah. Taraf signifikansinya dilakukan dengan uji lanjut menggunakan Uji Tuckey.

Tabel 1.

Rangkuman Hasil Perhitungan Analisis Varians (ANAVA) Dua Jalur

\begin{tabular}{|l|r|r|r|rr|l|l|}
\hline \multirow{2}{*}{ Sumber Variansi } & \multirow{2}{*}{ Db } & \multirow{2}{*}{ JK } & \multirow{2}{*}{ RJK } & \multirow{2}{*}{ F hitung } & \multicolumn{2}{|l|}{ Ftabel } \\
\cline { 5 - 9 } & & & & & $\mathbf{0 . 0 5}$ & $\mathbf{0 . 0 1}$ \\
\hline Strategi Pembelajaran (A) & 1 & 38.28 & 38.28 & 7.595 & $*$ & 4.20 & 7.64 \\
\hline Berpikir Kritis (B) & 1 & 0.28 & 0.28 & 0.056 & 4.20 & 7.64 \\
\hline Interaksi (A x B) & 1 & 371.28 & 371.28 & 73.664 & $* *$ & 4.20 & 7.64 \\
\hline Dalam & 28 & 141.13 & 5.04 & & & & \\
\hline Total Direduksi & 31 & 550.97 & & & & & \\
\hline
\end{tabular}

Secara signifikan terdapat interaksi antara strategi pembelajaran dan kemampuan berpikir kritis yang dibuktikan dengan $F_{\text {hitung }} 73.664>F_{\text {tabel }} 4.20$.

Hasil belajar sejarah siswa yang diberikan strategi pembelajaran PBL lebih tinggi dari hasil belajar siswa yang diberikan strategi pembelajaran langsung. 
Hipotesis statistik dirumuskan sebagai berikut:

$\mathrm{H}_{0}: \mu \mathrm{A}_{12} \leq \mu \mathrm{A}_{2}$

$\mathrm{H}_{1}: \mu \mathrm{A}_{1}>\mu \mathrm{A}_{2}$

Keterangan:

$\mu_{\mathrm{A} 1}$ : Rata-rata skor hasil belajar sejarah yang diberikan strategi pembelajaran PBL

$\mu_{\mathrm{A} 2}$ : Rata-rata skor hasil belajar sejarah yang diberikan strategi pembelajaran langsung

Hasil perhitungan ANAVA dua jalur diperoleh Fhitung untuk strategi pembelajaran sebesar 7.595 sedangkan $\mathrm{F}_{\text {tabel }}=4.20$ pada taraf nyatanya $\alpha=0,05$, karena nilai $F_{\text {hitung }}>\mathrm{F}_{\text {tabel, }}$ maka $\left(\mathrm{H}_{0}\right)$ ditolak dan $\mathrm{H}_{1}$ diterima artinya bahwa terdapat perbedaan hasil belajar sejarah antara siswa yang diberikan strategi pembelajaran PBL dan langsung.

Hasil Fhitung diketahui bahwa terdapat pengaruh hasil belajar sejarah antara siswa yang diberikan strategi pembelajaran PBL dengan siswa yang diberikan strategi pembelajaran langsung dan dilihat dari nilai rata-rata skor strategi pembelajaran PBL $\left(\mathrm{A}_{1}\right)$ 26.63, sedangkan nilai rata-rata skor strategi pembelajaran langsung $\left(\mathrm{A}_{2}\right)$ 24.94. Kesimpulannya hasil belajar sejarah siswa yang diberikan strategi pembelajaran PBL lebih tinggi dari siswa yang diberikan strategi pembelajaran langsung.

Terdapat pengaruh interaksi antara strategi pembelajaran dan kemampuan berpikir kritis terhadap hasil belajar sejarah siswa.

Hipotesis statistik dirumuskan sebagai berikut:

$\mathrm{H}_{0}$ : INT. $\mathrm{A} \times \mathrm{B}=0$

$\mathrm{H}_{1}$ : INT. $\mathrm{A} \times \mathrm{B} \neq 0$

Keterangan:

$\mathrm{H}_{0} \quad$ : Tidak terdapat pengaruh interkasi antara strategi pembelajaran dan kemampuan berpikir kritis terhadap hasil belajar sejarah siswa

$\mathrm{H}_{1} \quad$ : Terdapat pengaruh interaksi strategi pembelajaran dan kemampuan berpikir kritis terhadap hasil belajar sejarah siswa

Hasil perhitungan ANAVA bahwa Fhitung untuk faktor interaksi yaitu 73.664 lebih besar daripada $F_{\text {tabel }}$ yaitu 4.20 pada taraf nyata $\alpha=0.05$. Terdapat pengaruh interaksi antara penggunaan strategi pembelajaran dan kemampuan berpikir kritis siswa terhadap hasil belajar siswa. Data menyimpulkan bahwa $\mathrm{H}_{0}$ ditolak dan $\mathrm{H}_{1}$ diterima. Skor nilai rata-rata tiap sel diperoleh pada kelompok $\mathrm{A}_{1} \mathrm{~B}_{1}$ yaitu 29.63, $\mathrm{A}_{1} \mathrm{~B}_{2}$ 23.63, $\mathrm{A}_{2} \mathrm{~B}_{1}$ 21.63, $\mathrm{A}_{2} \mathrm{~B}_{2}$ 28.25.

Hipotesis ketiga menunjukkan hasil belajar sejarah yang diberikan strategi pembelajaran PBL lebih tinggi dari yang diberikan strategi pembelajaran langsung pada siswa yang memiliki kemampuan berpikir kritis tinggi. Skor rata-rata hasil belajar sejarah siswa yang diberikan strategi 
pembelajaran PBL dan memiliki kemampuan berpikir kritis $\left(\mathrm{A}_{1} \mathrm{~B}_{1}\right)$ adalah 30.63 sedangkan skor rata-rata hasil belajar sejarah yang diberikan strategi pembelajaran langsung dan memiliki kemampuan berpikir kritis tinggi $\left(A_{2} B_{1}\right)$ adalah 21.63. Rata-rata skor jika dibandingkan dengan mengguna- kan Uji Tuckey menunjukkan bahwa Qhitung yaitu $11.34>$ Qtabel yaitu 4.04 pada taraf signifikansinya $\alpha=0,05$, dengan demikian dapat disimpulkan $\mathrm{H}_{0}$ ditolak dan $\mathrm{H}_{1}$ diterima yang berarti bahwa hasil belajar siswa yang diberikan strategi pembelajaran PBL dengan kemampuan berpikir kritis tinggi lebih tinggi dari siswa yang diberikan strategi pembelajaran langsung.

Hipotesis keempat menunjukkan hasil belajar sejarah yang diberikan strategi pembelajaran PBL lebih rendah dari yang diberikan strategi pembelajaran langsung pada siswa yang memiliki kemampuan berpikir kritis rendah. Skor rata-rata hasil belajar sejarah siswa yang diberikan strategi pembelajaran PBL dan memiliki kemampuan berpikir kritis rendah $\left(A_{1} B_{2}\right)$ adalah 23.63 sedangkan skor rata-rata hasil belajar sejarah siswa yang diberikan strategi pembelajaran langsung dan memiliki kemampuan berpikir kritis rendah $\left(\mathrm{A}_{2} \mathrm{~B}_{2}\right)$ adalah 28.25. Rata-rata skor jika dibandingkan menggunakan Uji Tuckey hasil menunjukkan bahwa Qhitung yaitu 5.83 lebih besar daripada Qtabel yaitu 4.04 pada taraf signifikansinya $\alpha=0,05$, dengan demikian dapat disimpulkan $\mathrm{H}_{0}$ ditolak dan $\mathrm{H}_{1}$ diterima yang berarti bahwa bahwa untuk siswa diberikan strategi pembelajaran PBL dengan kemampuan berpikir kritis rendah terdapat perbedaan hasil belajar dengan siswa yang diberikan strategi pembelajaran langsung.

\section{PEMBAHASAN}

Penelitian ini bertujuan untuk mengetahui pengaruh strategi pembelajaran dan kemampuan berpikir kritis terhadap hasil belajar sejarah siswa SMA Negeri 72 Jakarta. Hasil penelitian menunjukkan bahwa penggunaan strategi pembelajaran PBL berpengaruh dalam meningkatkan hasil belajar sejarah siswa dan mendorong siswa aktif dalam kegiatan pembelajaran.

Hasil pengujian hipotesis pertama menunjukkan bahwa hasil belajar siswa yang diberikan strategi pembelajaran PBL lebih tinggi dari hasil belajar sejarah siswa yang diberikan strategi pembelajaran langsung. Strategi pembelajaran PBL tidak belajar tentang konsep tetapi mengolah informasi sehingga siswa mampu menganalisis masalah dan menyelesaikan masalah. Proses pembelajaran yang menggunakan strategi pembelajaran PBL dianggap lebih mampu meningkatkan kemampuan berpikir kritis siswa dibandingkan dengan pembelajaran langsung. Pembelajaran langsung merupakan pembelajaran yang biasanya digunakan guru yang bersifat konvensional.

Proses pembelajaran yang menggunakan strategi pembelajaran PBL dianggap lebih mampu meningkatkan kemampuan berpikir kritis siswa 
dibandingkan dengan pembelajaran langsung. Pembelajaran langsung hanya menuntut siswa untuk memahami dan menghafal materi sehingga siswa beranggapan materi sejarah merupakan pelajaran hafalan. Penerapan kedua strategi pembelajaran akan menghasilkan hasil belajar yang berbeda karena kecenderungan yang muncul dari strategi pembelajaran PBL adalah siswa dapat memanfaatkan sumber belajar dengan tepat dan mengolah peristiwa sejarah sehingga pelajaran tersebut lebih bermakna.

Hasil pengujian hipotesis kedua menunjukkan bahwa terdapat pengaruh interaksi antara penggunaan strategi pembelajaran dan kemampuan berpikir kritis siswa terhadap hasil belajar sejarah. Interaksi yang terjadi antara keduanya mempengaruhi hasil belajar, namun pengaruh tersebut tergantung pada variabel bebas lainnnya, seperti strategi pembelajaran yang dipadukan dengan kemampuan berpikir kritis. Ketepatan dalam pemilihan strategi pembelajaran akan menghasilkan pembelajaran yang berkualitas dan terarah pada tujuan yang jelas. Strategi yang sesuai dengan tingkat kemampuan berpikir kritis siswa sangat menentukan hasil belajar sejarah karena pelajaran sejarah yang berorientasi pada peristiwa menuntut siswa untuk dapat menganalisis bukan menghafal.

Hasil pengujian hipotesis ketiga menunjukkan bahwa hasil belajar sejarah yang diberikan strategi pembelajaran PBL lebih tinggi dari yang diberikan strategi pembelajaran langsung pada siswa yang memiliki kemampuan berpikir kritis tinggi. Keterlibatan siswa dalam proses pembelajaran sangat tinggi karena pembelajaran tersebut melatih keterampilan berpikir siswa sehingga mudah bagi siswa untuk mengemukakan pendapat dan mengajukan pertanyaan. Berbeda dengan pembelajaran langsung, siswa yang memiliki kemampuan berpikir kritis tinggi mengalami kesulitan untuk menggunakan keterampilan berpikir tetapi lebih berorientasi pada daya ingat.

Hasil pengujian hipotesis keempat menunjukkan bahwa hasil belajar yang diberikan strategi pembelajaran PBL lebih rendah dari yang diberikan strategi pembelajaran langsung pada siswa yang memiliki kemampuan berpikir kritis rendah. Strategi pembelajaran langsung tidak menuntut siswa untuk lebih aktif dan dominan sehingga siswa dengan kemampuan berpikir kritis rendah lebih suka menerima informasi dan pengarahan langsung dari guru. Keberhasilan pembelajaran langsung bergantung pada proses penyampaian informasi dari guru sehingga siswa dengan kemampuan berpikir kritis rendah dapat memahami materi dan mengikuti pembelajaran dengan maksimal.

\section{PENUTUP}

Hasil penelitian ini menunjukkan bahwa: (1) hasil belajar sejarah siswa yang diberikan strategi pembelajaran PBL lebih tinggi dari hasil belajar sejarah siswa yang diberikan strategi pembelajaran langsung (2) terdapat pengaruh 
interaksi antara strategi pembelajaran dan kemampuan berpikir kritis siswa terhadap hasil belajar sejarah (3) hasil belajar sejarah siswa yang memiliki kemampuan berpikir kritis tinggi dan diberikan strategi pembelajaran PBL lebih tinggi dari yang diberikan strategi pembelajaran langsung pada (4) hasil belajar sejarah siswa yang memiliki kemampuan berpikir kritis rendah dan diberikan strategi pembelajaran PBL lebih rendah dari yang diberikan strategi pembelajaran langsung.

Penelitian ini berimpikasi pada: (1) Pemilihan strategi pembelajaran sejarah. Strategi pembelajaran PBL cocok digunakan dalam pembelajaran sejarah karena dapat meningkatkan hasil belajar sejarah. Melalui strategi pembelajaran PBL siswa diantarkan untuk dapat menganalisis masalah, mengumpulkan dan mengolah data, aktif dalam interaksi, dan memiliki kemampuan untuk memecahkan masalah secara individu maupun kelompok. (2) Upaya untuk mencapai hasil belajar sejarah ditentukan oleh faktor strategi pembelajaran dan kemampuan berpikir kritis. (3) Siswa yang memiliki kemampuan berpikir kritis tinggi lebih sesuai jika diberikan strategi pembelajaran PBL. Siswa dapat memanfaatkan dengan optimal kemampuan berpikir yang dimiliki ketika diberikan masalah untuk dipecahkan. (4) Siswa yang memiliki kemampuan berpikir kritis rendah lebih sesuai jika diberikan strategi pembelajaran langsung. Siswa dengan kemampuan berpikir kritis rendah cenderung bergantung pada penjelasan dan arahan guru sehingga proses pembelajaran dirasa lebih efisien dan dapat meningkatkan hasil belajar.

\section{DAFTAR PUSTAKA}

[1] Agung Leo dan Wahyuni Sri. 2013. Perencanaan Pembelajaran Sejarah. Yogyakarta: Ombak,

[2] Basri Hasan. 2015. Paradigma Bari Sistem Pembelajaran. Bandung: Pustaka Setia

[3] Gagne, Robert M. et al. 2005. Principle Of Instructional Design. New York: Wadsworth Publishing.

[4] Moore Brooke Noel and Parker Richard. 2012Critical Thinking. New York: McGraw Hill

[5] Reigeluth Charles M., Alison, and Chellman Carr. 2009. Instructional Design Theories and Model Building a Common Knowledge Base. New York: Utledge

[6] Richey, Rita C. James D. Klein, Monica W. Tracey. 2011. The Instructional Design Knowledge Base: Theory, Research, and Practice. New York: Routledge 
[7] Satish Nargundkar. 2014. "A Guide Problem Based Learning (PBL) Approach: Impact on Critical Thinking". Journal of Innovative Education, Vol. 12. No.2, USA

[8] Sugiyono. 2015. Statistiska Untuk Penelitian. Bandung: Alfabeta

[9] Spector J Michael., Lockee Barbara B., Smaldino Sharon E and Hering Marry C. 2013. Learning, Problem Solving, and Mindtools. New York: Routledge 